\title{
Influence of Fuel Injection System and Engine-Timing Adjustments on Regulated Emissions from Four Biodiesel Fuels
}

\author{
Christopher Depcik, Joshua Jachuck, Dylan Jantz, Farshid Kiani, Michael Mangus, \\ Jonathan Mattson, Edward Peltier, and Susan M. Stagg-Williams
}

\begin{abstract}
The use of biofuels for transportation has grown substantially in the past decade in response to federal mandates and increased concern about the use of petroleum fuels. As biofuels become more common, it is imperative to assess their influence on mobile source emissions of regulated and hazardous pollutants. This assessment cannot be done without first obtaining a basic understanding of how biofuels affect the relationship between fuel properties, engine design, and combustion conditions. Combustion studies were conducted on biodiesel fuels from four feedstocks (palm oil, soybean oil, canola oil, and coconut oil) with two injection systems, mechanical and electronic. For the electronic system, fuel injection timing was adjusted to compensate for physical changes caused by different fuels. The emissions of nitrogen oxides $\left(\mathrm{NO}_{\mathrm{x}}\right)$ and partial combustion products were compared across both engine injection systems. The analysis showed differences in $\mathrm{NO}_{\mathrm{x}}$ emissions based on hydrocarbon chain length and degree of fuel unsaturation, with little to no $\mathrm{NO}_{x}$ increase compared with ultra-low sulfur diesel fuel for most conditions. Adjusting the fuel injection timing provided some improvement in biodiesel emissions for $\mathrm{NO}_{\mathrm{x}}$ and particulate matter, particularly at lower engine loads. The results indicated that the introduction of biodiesel and biodiesel blends could have widely dissimilar effects in different types of vehicle fleets, depending on typical engine design, age, and the feedstock used for biofuel production.
\end{abstract}

Renewable, biomass-based fuel use in the transportation industry has grown enormously over the past decade. Biodiesel consumption in 2013 in the United States exceeded 1,300 million gal, compared with less than 30 million gal in 2004 (1). One of the largest drivers of increased biodiesel use has been the Environmental Protection Agency's implementation of Renewable Fuel Standards under the Energy Independence and Security Act of 2007. These standards implemented annual targets for the use of biodiesel and other biofuels, resulting in widespread biodiesel adoption throughout the

C. Depcik, J. Jachuck, D. Jantz, F. Kiani, J. Mattson, E. Peltier, and S. M. StaggWilliams, University of Kansas, 1530 West 15th Street, Lawrence, KS 66045. Alternate affiliation for J. Jachuck: University of Rochester, CPU Box 272034 , 500 Joseph C. Wilson Boulevard, Rochester, NY 14627-2034. Alternate affiliation for D. Jantz: Bethel College, 300 East 27th Street, North Newton, KS. Alternate affiliation for F. Kiani: Trinity Consultants, 8425 Pulsar Place, Suite 280, Columbus, $\mathrm{OH}$ 43240. M. Mangus, GE Transportation, 2901 East Lake Road, Erie, PA 16531. Corresponding author: E. Peltier, epeltier@ku.edu.

Transportation Research Record: Journal of the Transportation Research Board, No. 2503, Transportation Research Board, Washington, D.C., 2015, pp. 20-28. DOI: 10.3141/2503-03 transportation industry, primarily as blends with existing petroleum diesel fuels at ratios of $20 \%$ or less. For example, the ASTM standard for diesel fuels was updated in 2008 to allow for blending of up to $5 \%$ biodiesel fuel without separate labeling as long as biodiesel stock and blended fuels met their respective ASTM standards (ASTM D975-08a and subsequent versions). Most major automotive and light truck engine manufacturers have also provided for the use of up to $20 \%$ biodiesel blends in newer engines without affecting warranties (2). Furthermore, various states have adopted additional requirements for biodiesel content in retail diesel fuels (3) or for state agency fuel purchases (4).

As the use of biodiesel blends in on- and off-road vehicles becomes commonplace, it is necessary to assess the effect of these fuels on diesel mobile source emissions. Generally, the use of biodiesel has been shown to reduce emissions of unburned hydrocarbons (HC) and particulate matter (PM) (5-7). The effects of biodiesel use on nitrogen oxides $\left(\mathrm{NO}_{\mathrm{x}}\right)$, however, have been more difficult to assess. In 2002, the Environmental Protection Agency estimated that soybased biodiesel would result in approximately a $1 \%$ increase in $\mathrm{NO}_{\mathrm{x}}$ emissions for every $10 \%$ increase in biodiesel content compared with an average diesel fuel (7). However, significant variance in biodiesel $\mathrm{NO}_{\mathrm{x}}$ emissions has been observed from one experimental setup to another, with a significant minority of studies showing no significant increase (and sometimes decreases) in $\mathrm{NO}_{\mathrm{x}}$ caused by biodiesel use $(6,8)$. Studies conducted to compare biodiesel fuel blends with California Air Resources Board diesel fuels found increases in $\mathrm{NO}_{\mathrm{x}}$ emissions at all blending levels with soy-based biodiesel, but less effect from an animal-based fuel $(9,10)$. This is consistent with other results suggesting that more saturated biodiesel fuels may produce little to no increase in $\mathrm{NO}_{\mathrm{x}}$ compared with standard diesel fuels $(11,12)$. Differences in biodiesel physical properties can also alter fuel injection and combustion patterns, further impacting exhaust emissions profiles. In particular, fuel injection timing has been identified as a significant factor in $\mathrm{NO}_{\mathrm{x}}$ emissions (13-15). In older mechanical systems, higher biodiesel compressibility can result in an earlier injection. In newer engines, electronic fuel injectors can be adjusted to compensate for these differences, potentially reducing $\mathrm{NO}_{\mathrm{x}}$ formation.

Identifying the impacts of biodiesel use on exhaust emissions is of concern to engine manufacturers, who face increasingly stringent regulations on acceptable $\mathrm{NO}_{\mathrm{x}}$ and $\mathrm{PM}$ levels, and to air quality modelers. This identification can only be done by better understanding the underlying factors that produce these wide discrepancies in emissions results. Previously, the research team used a mechanical fuel injection system to examine the exhaust emissions of multiple biodiesel fuels from a single-cylinder research engine (12). More recently, the 
team conducted additional emissions studies with four identical fuels (palm, soybean, canola, and coconut oil biodiesel) in the same engine after installation of an electronic fuel injection system. [Results of the soybean and palm biodiesel tests with the electronic fuel injection system were published previously in Mangus et al. (16)]. This study analyzed the new and existing data to provide a unique assessment of how changes in the fuel injection system and engine timing can affect emissions of $\mathrm{NO}_{\mathrm{x}}$ and partial combustion products from identical biodiesel fuels in a simple engine system where variables can be more easily isolated. The results highlight the specific fuel property and engine configuration factors that can aid in the development of cleaner-burning systems.

\section{EXPERIMENTAL PROCEDURE}

\section{Fuel Preparation and Characterization}

Biodiesel fuels were prepared in a pilot-scale production facility at the University of Kansas. The mechanical fuel pump-line injector (MI) fuels and fuels for the 2013 electronic fuel injection (EI) tests were prepared from pure feedstocks of palm, soybean, coconut, and canola oils. The 2014 EI test fuels were prepared from used coconut and canola oils obtained from local restaurants. All biodiesels were produced through a transesterification process. Each oil was reacted with methanol at a $1: 6$ molar ratio at $60^{\circ} \mathrm{C}$ and 1 atmosphere in a continuous stir batch reactor, using basic catalysts (sodium methoxide or potassium hydroxide). After production, the fuels were washed and settled to remove glycerin, unreacted methanol, and other impurities and then dried thoroughly to remove water. Further details were presented in Cecrle et al. (12) and Mangus et al. (16).

Physical fuel properties were characterized according to ASTM standards. Kinematic viscosity was measured following ASTM standard D445, with a Koehler KV4000 Kinematic Viscosity Bath. Density was measured following ASTM standard D4052, with an Anton Paar 5000M Density Meter. Heating values were determined following ASTM standard D240, with a Parr 6200 Calorimeter. The carbon, hydrogen, and nitrogen contents for each fuel were determined with a PerkinElmer 2400 Series II CHNS/O Elemental Analyzer, with oxygen content determined by difference. The fatty acid methyl ester (FAME) profile of each biodiesel fuel was quantified with an Agilent 6890 Series GC System with a polyethylene glycol capillary column (19091N-231 HP-INNOWax from
Agilent), an Agilent 5973 Network Mass Selective Detector, and MSD ChemStation software. Full details of the GC-MS operating parameters are presented elsewhere (17). Samples were diluted for analysis in n-hexane, with ethyl stearate used as an internal standard. F.A.M.E. Mix C8-C24 (18918-1AMP from Sigma-Aldrich) was used as an analytical standard for peak comparison.

The FAME profile of each individual biodiesel was used to calculate the cetane number, unsaturation percentage, and average $\mathrm{HC}$ chain length for that fuel. Cetane numbers were calculated as mass weighted averages of accepted cetane numbers for the individual FAMEs, following the method in Garcia et al. (18). The unsaturation percentage was calculated by adding together the individual FAME fractions weighted by the number of double bonds in each molecule. A higher unsaturation percentage, thus, indicates the presence of more double bonds in the fuel's FAME components. Similarly, the average number of carbons in the HC chains of each fuel (not including the methyl ester) was calculated as a weighted average of the number of carbons in each individual FAME. The most common FAMEs present in the fuels were $\mathrm{C} 16$ to $\mathrm{C} 18$ compounds, except for the coconut biodiesel, which contained primarily $\mathrm{C} 12$ and $\mathrm{C} 14$.

\section{Combustion and Emissions Testing}

Both sets of experiments utilized a Yanmar L100V single-cylinder direct-injected diesel engine. Between the first set of experiments in 2011 and the subsequent testing in 2013-2014, the engine was substantially modified. The modification included replacement of the original MI with a common-rail EI system and the installation of equipment to monitor in-cylinder pressure during the combustion experiments (Table 1). In addition, the original electric generator was replaced with an AC dynamometer. For both systems, a MicroMotion Coriolis flow meter (CMF010M) was used to measure fuel flow rates, while a Merriam laminar flow element (50MW20-2) and Omega differential pressure transducer (PX277-30D5V) were used to measure air flow. A more complete description of the engine setup can be found in Langness et al. (19).

Common-rail experiments were conducted at $25 \%, 50 \%, 75 \%$, and $100 \%$ of rated engine load, corresponding to the values shown in Table 1. As the rated continuous generator power was only $\sim 85 \%$ of the rated engine load, the experiments with the mechanical fuel injection system were conducted at slightly lower engine torque. Each fuel was tested at all four engine loads. For each test, data

TABLE 1 Properties of the Engine Used in Biodiesel Combustion Studies

\begin{tabular}{lll}
\hline Engine Property & Mechanical Injection System, 2011 & Electronic Injection System, 2013-2014 \\
\hline Fuel injector & Mechanical fuel pump-line & Bosch common-rail fuel injection system \\
Injection timing ( ${ }^{\circ}$ before TDC) & $15.5 \pm 0.5$ & Adjustable \\
Speed (rpm) & 3,600 & 1,800 \\
Injection pressure (MPa) & 19.6 & 42.0 \\
Loading instrument & NorthStar 5500 belt-driven generator & $\begin{array}{c}\text { Dymond Series 12-Hp regenerative AC dynamometer } \\
\text { (Dyne Systems, Inc.) }\end{array}$ \\
Tested loads & $4.6,8.8,12.3$, and 15.6 N-m & $4.5,9.0,13.5$, and 18.0 N-m \\
Emission monitoring equipment & Semtech-DS mobile emission analyzer & $\begin{array}{c}\text { AVL SESAM-FTIR emissions bench + THC analyzer } \\
\text { AVL Smoke Meter 415 SE (PM) }\end{array}$ \\
In-cylinder pressure and volume & NA & Kistler piezoelectric transducer (6052C), Kistler charge \\
monitoring equipment & & amplifier (5011B), Kistler pulse multiplier (2614B4) \\
\hline
\end{tabular}

NOTE: $\mathrm{TDC}=$ top dead center; $\mathrm{THC}=$ total hydrocarbon; $\mathrm{NA}=$ not available. 
collection began once engine steady-state had been achieved, where steady-state was defined as a change in exhaust temperature of less than $1 \%$ per minute (19). Gaseous emissions data were recorded for $10 \mathrm{~min}$ at $1 \mathrm{sample} / \mathrm{s}$ for the MI studies, and for $5 \mathrm{~min}$ at $1 \mathrm{sample} / \mathrm{s}$ for the EI studies. Particulate emissions were recorded for the electronic fuel injection experiments only. Engine performance data were collected at a rate of 10 samples/s for 2 min during the emissions data collection. Reference tests at each engine load were conducted on the same day and in the same manner as biodiesel testing with biodieselfree ultra-low-sulfur diesel fuel (ULSD). More complete descriptions of the experimental procedures can be found in Cecrle et al. (12) and Mangus et al. (16) for the MI and EI systems, respectively.

\section{Injection-Timing Adjustment for Common-Rail System}

During the EI studies, in-cylinder pressure and volume data were collected from 60 thermodynamic cycles at a resolution of $0.2-0.5$ crank angle degrees, and then averaged to provide a pressure profile for each fuel tested at each load. With this profile, the injection timing of ULSD was calibrated for each load such that fuel consumption was minimized at the maximum brake torque condition (20), the point where the engine releases the maximum amount of energy. Maximum brake torque timing is highly dependent on ignition delay, which is much shorter for most biodiesels compared with ULSD (21), and will thus vary for the different fuels. Combustion tests for each fuel were first performed with the ULSD-calibrated injection timing. The in-cylinder pressure trace for each biodiesel was then compared with that of the ULSD control at each load. The timing of the peak in-cylinder pressure produced by the biodiesel was then adjusted to match that produced from ULSD by delaying fuel injection. This method ensured normalization of the combustion phasing to obtain a better representation of fuel property influences on exhaust emissions separate from the effects of injection-timing changes. Figure 1 shows the effects of this timing adjustment on in-cylinder pressure traces for the combustion of used coconut oil at 18.0 Newton-meters (N-m) (100\% load).

\section{Data Analysis}

Raw emissions data (in parts per million) were filtered to remove instrumental noise and then converted to brake-specific emissions

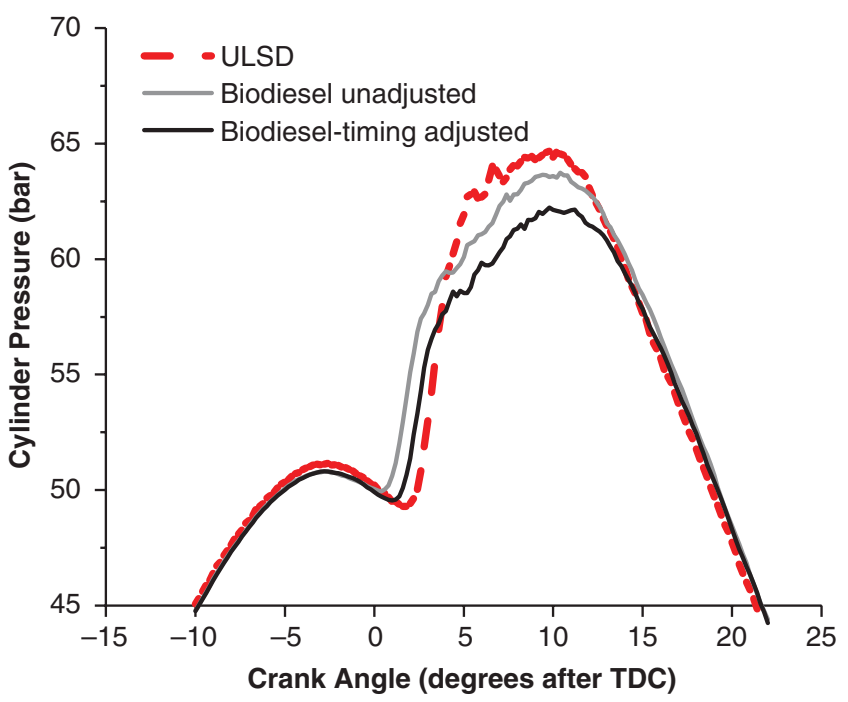

FIGURE 1 Normalization of peak pressure crank angle location for coconut biodiesel at $18 \mathrm{~N}-\mathrm{m}$.

(g/kW-h) with simultaneously recorded data on fuel flow and energy produced by the engine at a given load. An average emissions level was then calculated over the steady-state data collection period for each fuel at each engine load. For comparative purposes, averaged results were normalized by comparison with the emissions from the reference ULSD control fuel combusted under the same conditions. A normalized emissions level of $100 \%$ indicates that emissions from that particular fuel were equal to ULSD emissions from the same engine setup at the same load. This normalization allows for comparison of experiments conducted on different engine setups while controlling for day-to-day changes in ambient conditions that could affect levels of emissions.

\section{RESULTS AND DISCUSSION}

\section{Fuel Properties}

The physical and chemical properties of the biodiesel fuels used in these experiments are shown in Table 2. In general, measured prop-

TABLE 2 Properties of Biodiesel Fuels Used in Experiments

\begin{tabular}{|c|c|c|c|c|c|c|c|c|}
\hline \multirow[b]{2}{*}{ Property $^{a}$} & \multicolumn{2}{|l|}{ Palm } & \multicolumn{2}{|l|}{ Soybean } & \multicolumn{2}{|l|}{ Coconut } & \multicolumn{2}{|l|}{ Canola } \\
\hline & MI & EI & MI & EI & MI & EI & MI & EI \\
\hline Viscosity (cSt) & 4.64 & 4.51 & 4.22 & 4.17 & 2.72 & 2.62 & 4.63 & 4.64 \\
\hline Density $\left(\mathrm{kg} / \mathrm{m}^{3}\right)$ & 866.3 & 872.6 & 875.6 & 881.3 & 865.9 & 869.7 & 874.1 & 880.7 \\
\hline Heating value $(\mathrm{kJ} / \mathrm{kg})$ & 39,825 & 40,479 & 39,880 & 39,798 & 38,228 & 38,029 & 39,869 & 39,884 \\
\hline Oxygen mass (\%) & 11.1 & 10.2 & 9.9 & 9.9 & 14.4 & 13.4 & 9.6 & 9.2 \\
\hline Cetane number ${ }^{b}$ & 65 & 60 & 48 & 45 & 59 & 59 & 53 & 54 \\
\hline $\mathrm{HC}$ chain length ${ }^{c}$ & 17.0 & 17.3 & 17.7 & 17.8 & 12.4 & 13.0 & 17.8 & 17.9 \\
\hline Unsaturation (\%) & 50.4 & 62.9 & 85.3 & 85.5 & 5.2 & 8.2 & 93.9 & 89.2 \\
\hline
\end{tabular}

NOTE: $\mathrm{cSt}=$ centistokes.

${ }^{a}$ Uncertainties for measured properties are as follows: viscosity, $0.01 \mathrm{cSt}$; density, $0.01 \mathrm{~kg} / \mathrm{m}^{3}$; heating value, $40 \mathrm{~kJ} / \mathrm{kg}$; oxygen mass percentage, $0.3 \%$.

${ }^{b}$ Calculated according to Benjumea et al. (23).

${ }^{c}$ Average space of carbons in hydrocarbon chain, based on FAME analysis. 
erties for the biodiesel fuels were relatively similar between the two experiments, with density values varying by $<1 \%$, viscosity by $<4 \%$, and heating values by $<2 \%$. Chemical analysis revealed some compositional differences in the two palm biodiesels, with the fuel used for the EI system having a higher unsaturation level and lower oxygen content. The oxygen content of the EI that used coconut oil was also about $1 \%$ lower than that for the MI fuel. These differences, however, are relatively minor and do not affect the ranking of either fuel relative to the other tested biodiesels.

Consistent with generally observed trends, all biodiesel fuels had higher densities and lower heating values than the reference ULSD fuels (measured ULSD densities and heating values ranged between 835 and $839 \mathrm{~kg} / \mathrm{m}^{3}$ and 45,500 and 45,740 kJ/kg, respectively) (22). Three of the four biodiesel fuels had viscosities similar to each other but more than $50 \%$ higher than the ULSD viscosity, which ranged from 2.48 to 2.58 centistokes (cSt). The coconut biodiesel fuels, however, had viscosities much closer to that of ULSD than to the other biodiesel fuels. These fuels were also composed of shorter FAME compounds and contained almost no carbon-carbon double bonds ( $<10 \%$ unsaturation). The canola and soybean biodiesels contained almost all longer, unsaturated FAME compounds (primarily C18:1 and C18:2), while the palm biodiesel had similar chain length but less unsaturation and higher oxygen content.

\section{$\mathrm{NO}_{\mathrm{x}}$ Emissions}

Figure 2 presents $\mathrm{NO}_{\mathrm{x}}$ emissions for the MI system. In absolute terms, $\mathrm{NO}_{\mathrm{x}}$ emissions for the MI system decrease with increasing engine torque, with the greatest decrease occurring between the first and second load conditions (4.6 and $8.8 \mathrm{~N}-\mathrm{m}$, respectively). At $4.6 \mathrm{~N}-\mathrm{m}$ (around $25 \%$ total engine load), all biodiesel fuels except palm have total brake-specific emissions roughly equal to ULSD

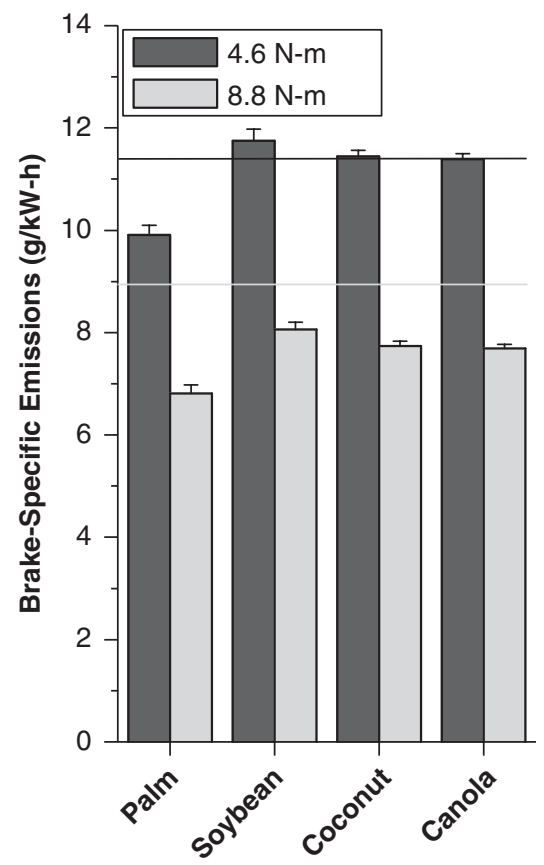

(a) emissions (heavy line in Figure 2). By the highest engine load conditions, however, all biodiesel fuels have lower brake-specific emissions than ULSD. Given the differences in testing conditions mentioned before, the absolute levels of brake-specific emissions are not directly comparable between the two systems. Instead, the level of biodiesel emissions relative to the simultaneously tested ULSD fuel is used in assessing the response of the different fuels. Figure 3 shows this trend more clearly by focusing only on emissions as a percentage of the corresponding ULSD emissions. For all four fuels, $\mathrm{NO}_{\mathrm{x}}$ emissions decrease relative to ULSD at all loads, with the greatest change above $12.3 \mathrm{~N}-\mathrm{m}$ ( $\sim 75 \%$ load).

The EI system, by contrast, shows somewhat different behavior. As with the previous system, brake-specific $\mathrm{NO}_{\mathrm{x}}$ emissions decrease with increased engine load. However, at the lowest engine load setting, $\mathrm{NO}_{\mathrm{x}}$ emissions for all four biodiesel fuels are significantly below those for ULSD. The relative level of biodiesel and ULSD NO emis- $^{-}$ sions remains relatively consistent through the second and third engine settings for the coconut and canola biodiesel, but increases for palm and soybean (again, the overall brake-specific emissions decrease in each case, but the ULSD decrease is greater than the decrease for these fuels, so their relative emissions increase). By the highest load $(18 \mathrm{~N}-\mathrm{m}), \mathrm{NO}_{\mathrm{x}}$ emissions from all fuels except the palm biodiesel are equivalent to or just below the ULSD emission levels when engine timing is not adjusted. Figure 3 indicates the results when timing is not adjusted (i.e., most comparable to the MI studies, with the engine as is) and when injection is delayed to match peak pressure location and remove ignition delay effects. Overall, the use of the EI system generally leads to lower biodiesel $\mathrm{NO}_{\mathrm{x}}$ emissions relative to ULSD, but the effect is much smaller as the engine torque increases, which is opposite to the pattern observed for the MI system.

As shown in Figures 3 and 4, after adjusting the engine timing, $\mathrm{NO}_{\mathrm{x}}$ emissions are reduced compared with the unadjusted condition for all fuels at all engine torque settings. The difference is relatively small,

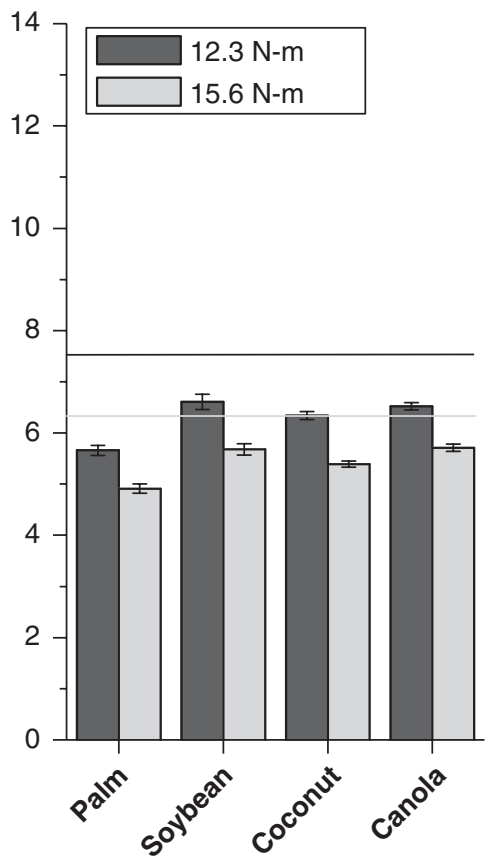

(b)

FIGURE $2 \quad \mathrm{NO}_{\mathrm{x}}$ emissions for the MI engine: $(a) 25 \%$ and $50 \%$ loads and $(b) 75 \%$ and $100 \%$ loads (solid lines are ULSD emissions levels at the same loads). 


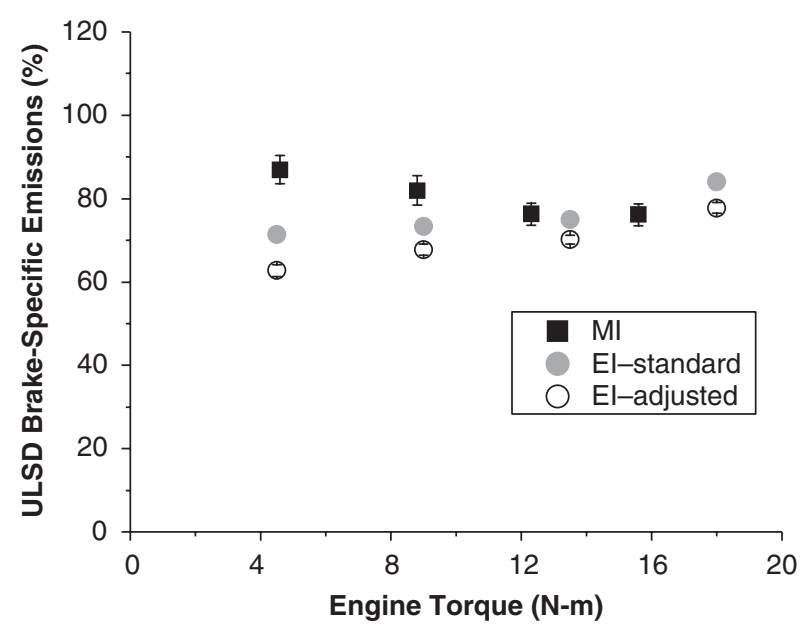

(a)

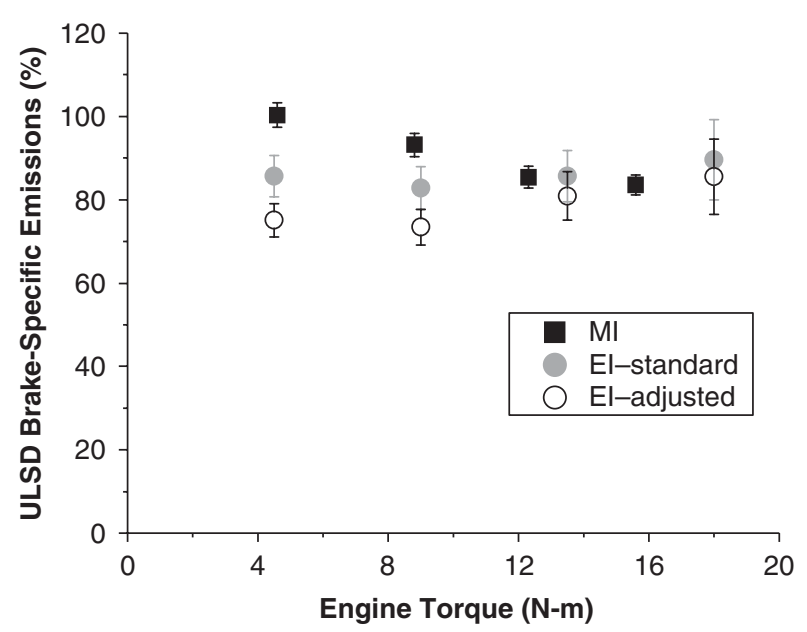

(c)

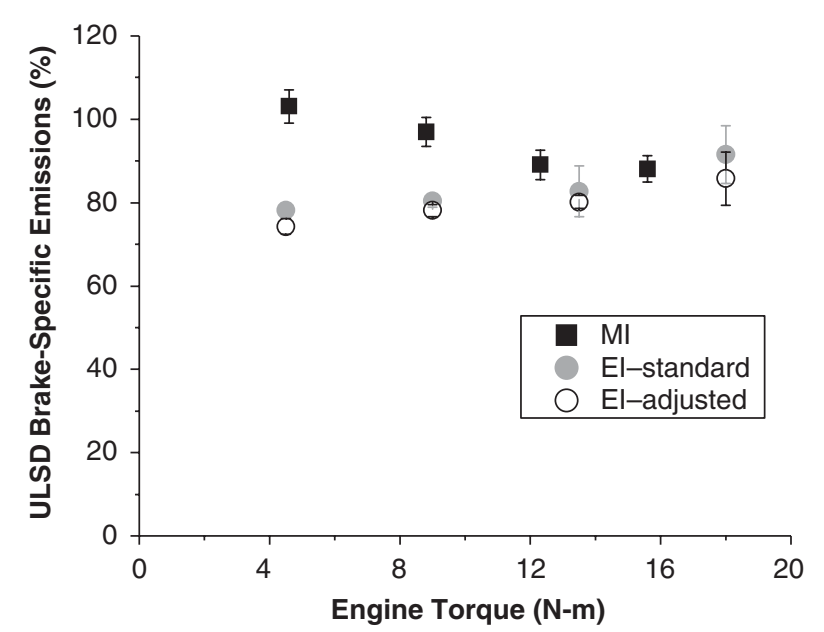

(b)

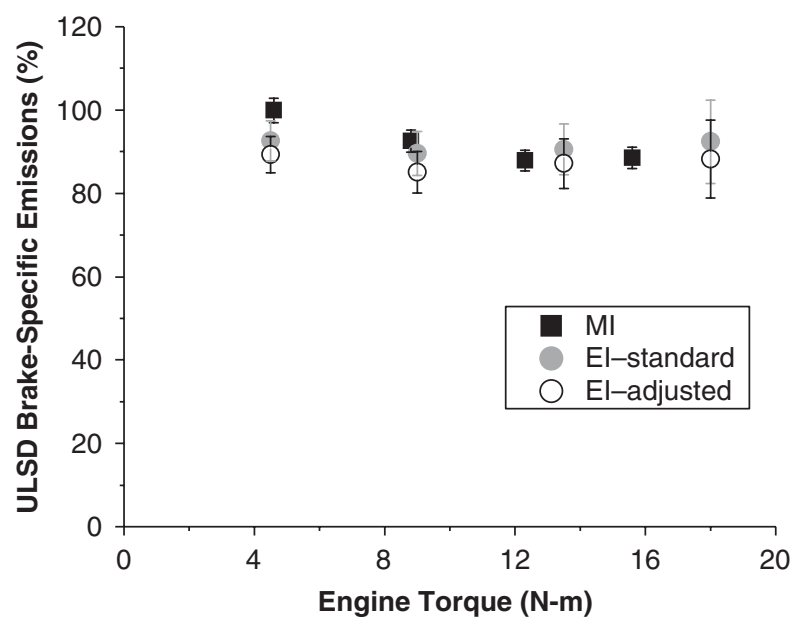

(d)

FIGURE 3 Normalized $\mathrm{NO}_{x}$ emissions under dissimilar fuel injection strategies: (a) palm biodiesel, (b) soybean biodiesel, (c) coconut biodiesel, and $(d)$ canola biodiesel.

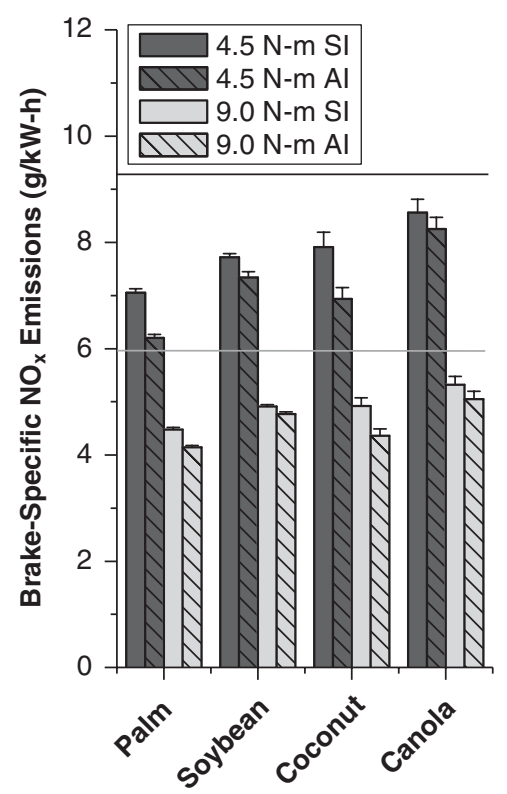

(a)

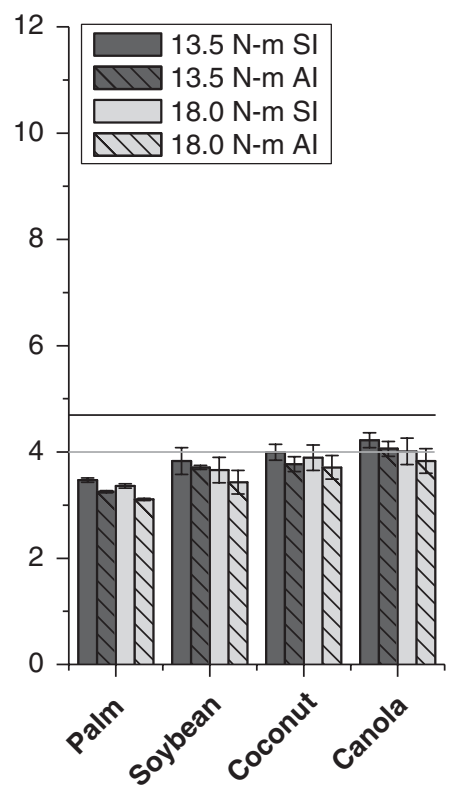

(b)

FIGURE $4 \quad \mathrm{NO}_{\mathrm{x}}$ emissions for the El engine with standard injection (SI) and timing adjusted injection (AI): (a) 25\% and 50\% loads and (b) $75 \%$ and $100 \%$ loads (solid lines are ULSD emissions levels at the same loads). 
and not all individual results are significantly different from the unadjusted values within the uncertainty of the measurements. However, a statistical analysis of the 16 paired data points resulting from the EI experiments (four fuels each at four engine settings) indicates that the average decrease in brake-specific $\mathrm{NO}_{x}$ emissions when the engine timing is adjusted is $6.3 \pm 1.5 \%$ (at a $95 \%$ confidence interval). This analysis suggests that adjusting injection timing does in fact reduce overall $\mathrm{NO}_{\mathrm{x}}$ emissions, as anticipated because of a reduction in combustion pressures and temperatures. When broken down by individual biodiesel fuel, timing adjustment had the largest influence on palm and coconut biodiesels, with average $\mathrm{NO}_{\mathrm{x}}$ reductions of $8.4 \pm 2.5 \%$ and $8.4 \pm 3.9 \%$, respectively. For soybean and canola biodiesels, the average $\mathrm{NO}_{\mathrm{x}}$ reductions were $4.3 \pm 1.6 \%$ and $4.2 \pm 0.7 \%$, respectively.

Throughout these experiments, palm biodiesel consistently had the lowest $\mathrm{NO}_{\mathrm{x}}$ emissions for the $\mathrm{MI}$ and EI systems. Palm biodiesel has a lower level of unsaturated (double-bond) carbons in its composition than either soybean or canola oil, which has been theorized to improve $\mathrm{NO}_{\mathrm{x}}$ emissions by reducing energy release, and thus thermal $\mathrm{NO}_{\mathrm{x}}$ production (23). In an earlier study with the EI setup, a beef tallow biodiesel with similar FAME composition as palm also had lower $\mathrm{NO}_{\mathrm{x}}$ emissions than the more unsaturated fuels (16). These results are also consistent with the differences in soy and animal-based biodiesel

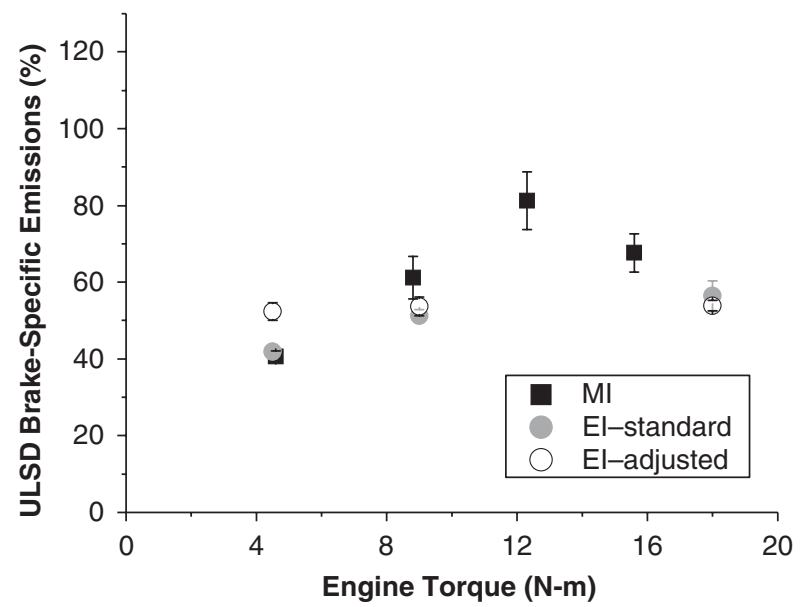

(a)

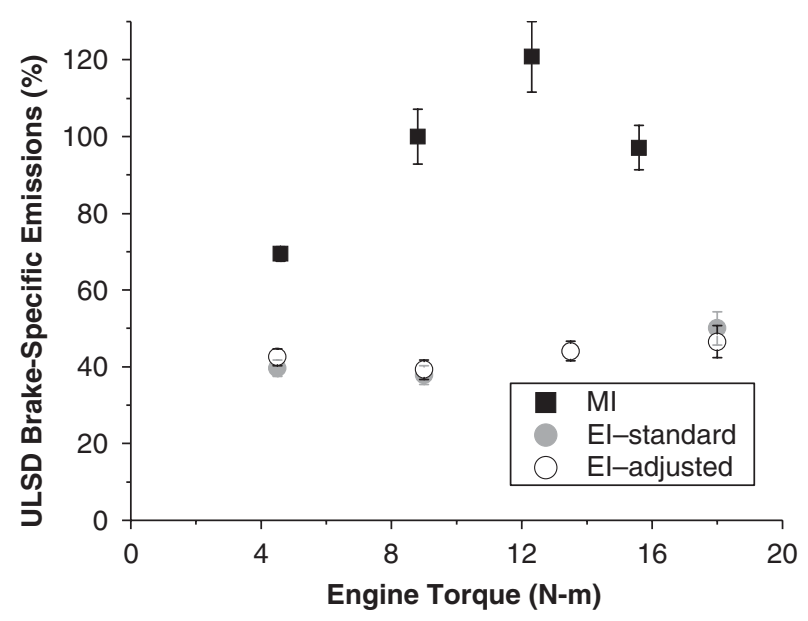

(c)
$\mathrm{NO}_{\mathrm{x}}$ emissions recorded in the most recent California Air Resources Board study (9). Coconut biodiesel, by contrast, has very low unsaturation levels, yet had higher $\mathrm{NO}_{\mathrm{x}}$ emissions than palm biodiesel in both experiments. Investigating the fuel properties in Table 2, coconut biodiesel has shorter average $\mathrm{HC}$ chains than the other biodiesel fuels, resulting in a much lower viscosity, which promotes better breakup of the fuel spray during the injection process (smaller droplets). Coupled with a higher oxygen percentage, this will result in a more enhanced combustion process promoting a faster burn and higher temperatures, which cause higher $\mathrm{NO}_{\mathrm{x}}$ emissions.

\section{Partial Combustion Products}

The influence of biodiesel use on $\mathrm{HC}$ emissions is presented in Figure 5. As expected, the use of biodiesel results in reduced emissions of uncombusted $\mathrm{HC}$ in almost all cases for the MI and EI systems. This decrease is primarily caused by the inherent fuel properties of the biodiesels that result in more complete combustion, that is, molecular oxygen within the fuel structure; the dominance of shorter, straight chain HC compounds; and the lack of aromatic compounds. With the MI system, brake-specific HC emissions for all fuels except coconut

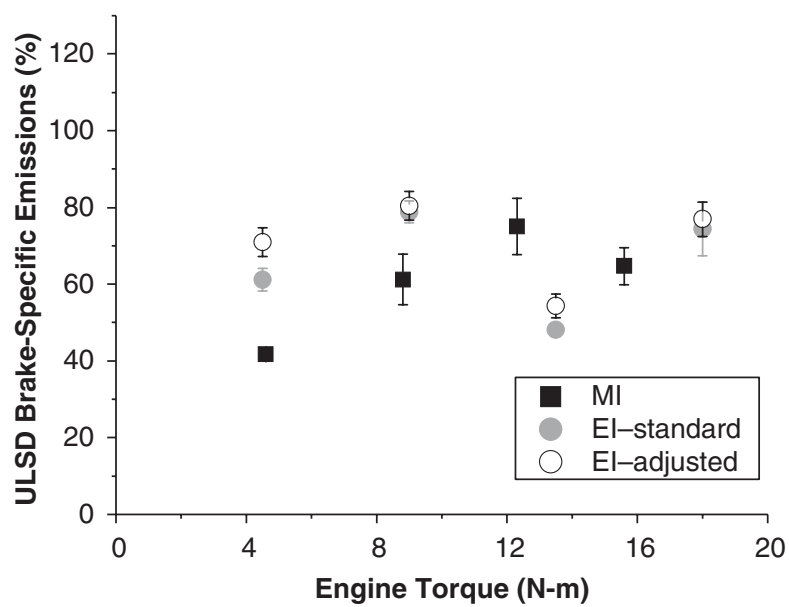

(b)

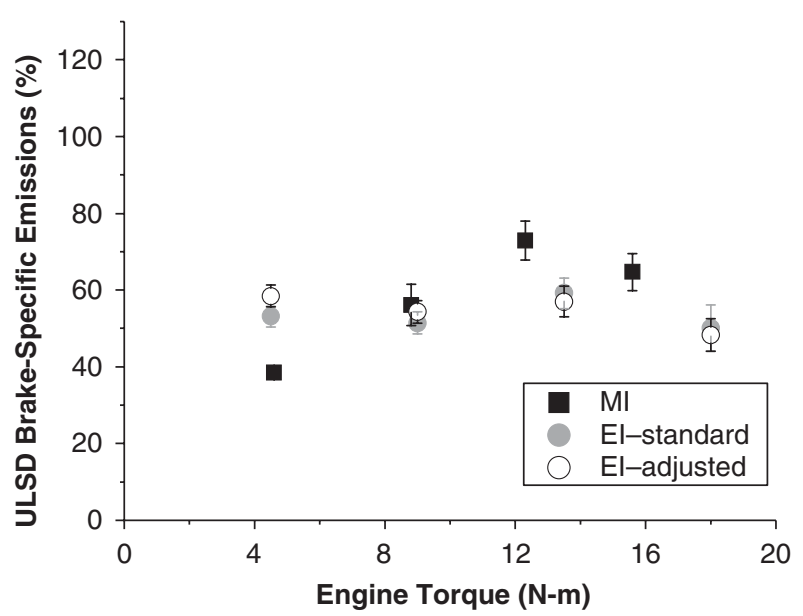

(d)

FIGURE 5 Normalized HC emissions under dissimilar fuel injection strategies: (a) palm biodiesel, (b) soybean biodiesel, (c) coconut biodiesel, and (d) canola biodiesel. 
biodiesel are reduced by $20 \%$ to $60 \%$, with the greatest reductions occurring at lower engine loads.

Adjusting the injection timing for the EI system resulted in only small changes in $\mathrm{HC}$ emissions. Unlike for $\mathrm{NO}_{\mathrm{x}}$ emissions, increases and decreases in brake-specific $\mathrm{HC}$ emissions were observed because of this adjustment. Comparing the percentage change between paired sets of unadjusted and timing adjusted $\mathrm{HC}$ emissions data, the overall average change was $-4.5 \pm 4.1 \%$, indicating a slight increase in $\mathrm{HC}$ emissions (a reduction in combustion temperature with timing reduces $\mathrm{NO}_{\mathrm{x}}$ but increases $\mathrm{HCs}$ ). For the individual fuels, only soybean biodiesel, with an average change of $-8.6 \pm 6.7 \%$, had an increase significantly distinct from zero. In addition, the overall average was driven by the relatively large growth observed at $4.5 \mathrm{~N}-\mathrm{m}$ for the palm and soybean biodiesels. At higher loading, no significant effect of timing adjustment on $\mathrm{HC}$ emissions was observed in either direction.

Carbon monoxide (CO) emissions (not shown) with the MI system followed generally similar patterns as $\mathrm{HC}$ for three of the four fuels. Palm and soybean CO emissions were reduced by $20 \%$ to $50 \%$ compared with ULSD, with the greatest reductions at lower engine loads. Coconut emissions increased over ULSD emissions at $9 \mathrm{~N}-\mathrm{m}$ load and greater. Canola $\mathrm{CO}$ emissions also increased compared with ULSD; however, canola $\mathrm{CO}$ emissions did not follow the HC profile. For coconut and canola biodiesels, normalized emissions with the EI system were much lower, ranging from $60 \%$ to $100 \%$ of ULSD. Palm and soy normalized emissions were not substantially affected by converting from the MI to the EI system. The coconut biodiesel is more sensitive to changes in the injection system because of fuel properties that promote quick combustion. The EI system allows for injection of smaller, finer droplets that combust more readily, particu- larly with the oxygenated biodiesel fuels, reducing partial combustion products. Canola has the highest level of unsaturation percentage (the most double carbon bonds and the largest amount of C18:3), which increases the difficulty in converting fuel carbon to carbon dioxide, and could promote $\mathrm{CO}$ emissions versus full combustion to carbon dioxide. However, the properties of canola are not too dissimilar to soybean; therefore, a definitive conclusion as to why canola $\mathrm{CO}$ emissions are more sensitive to the fuel injection strategy than soy or palm biodiesel cannot be determined. With the EI system, $\mathrm{CO}$ emissions are below ULSD levels for all loads below $18 \mathrm{~N}-\mathrm{m}$ load.

As with the $\mathrm{HC}$ emissions, the $\mathrm{CO}$ emissions increased with the adjusted injection timing, again most likely because of the lower combustion temperatures. The mean difference from the unadjusted to the timing adjusted condition over the whole set of data was $-7.1 \pm 5.2 \%$, or an increase in $\mathrm{CO}$ emissions of $7.1 \%$. In addition, all biodiesel fuels except canola had individual increases that were statistically significant, with palm biodiesel showing the highest increase of $10.4 \pm 4.5 \%$.

PM emissions were not collected during the MI studies; thus, the impact of different fuel injection strategies cannot be addressed. With the EI system, PM emissions increased relative to ULSD for all fuels at $4.5 \mathrm{~N}-\mathrm{m}$ (Figure $6 a$ ), but decreased at $18 \mathrm{~N}$-m (Figure 6b). At 9 and $13.5 \mathrm{~N}-\mathrm{m}$, differences emerged between the fuels, with palm and soybean PM emissions higher than their baseline ULSD fuel and coconut and canola PM emissions lower. To some extent, these results suggest a trade-off in $\mathrm{NO}_{\mathrm{x}}$ versus $\mathrm{PM}$ emissions for the biodiesel fuels as a function of the relative levels of premixed or diffusion burn. Palm and soy biodiesel fuels showed the greatest PM increases (relative to ULSD) at low loads, where the decrease in $\mathrm{NO}_{\mathrm{x}}$ was also the great-

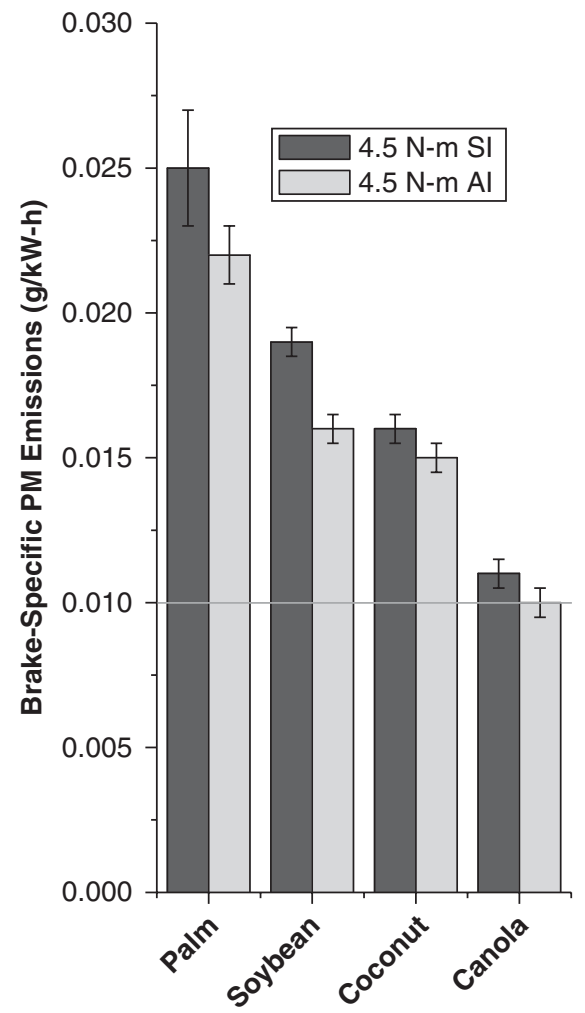

(a)

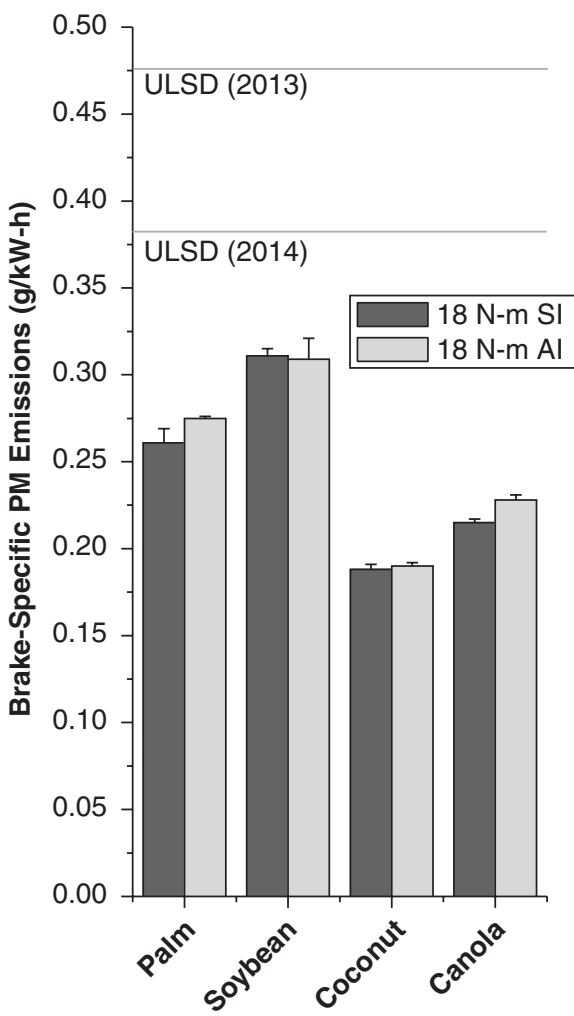

(b)

FIGURE 6 PM emissions for biodiesel fuels with electronic fuel injection: (a) $25 \%$ load and (b) $100 \%$ load (solid lines are ULSD emission levels at the same loads). 
est. This is because combustion conditions that favor lower $\mathrm{NO}_{\mathrm{x}}$ production (particularly premixed burn) will typically also favor increased PM formation (increased diffusion burn). At the same time, the coconut and canola biodiesel results showed decreases in $\mathrm{NO}_{\mathrm{x}}$ and PM relative to ULSD, from $25 \%$ to $75 \%$ load. These results indicate that some biodiesel fuels may simply be less likely to produce PM emissions because of differences in the fuel properties.

None of the four fuels tested showed a consistent effect of timing adjustment on PM emissions over the full range of experimental conditions. Instead, PM emission responses were tied to engine load. At $4.5 \mathrm{~N}-\mathrm{m}$, the mean difference in PM emissions from unadjusted to adjusted timing conditions was $-10.8 \pm 4.1 \%$ over all four fuels, while at $13.5 \mathrm{~N}-\mathrm{m}$ it was $-5.6 \pm 0.9 \%$. At 9 and $18 \mathrm{~N}-\mathrm{m}$, by contrast, the effect of timing adjustment was not significant in either direction. This variation may be partially caused by the overall low total levels of PM emissions, which were $<0.1 \mathrm{~g} / \mathrm{kW}$-h for all loads below $18 \mathrm{~N}-\mathrm{m}$. ULSD PM emissions, unlike those of the gas phase constituents, were also significantly different in the 2013 and 2014 tests, except at $4.5 \mathrm{~N}-\mathrm{m}$. (Therefore, two lines are indicated for ULSD in Figure $6 b$.) The difference suggests that the PM emission results from this system may be more susceptible to small differences in experimental conditions from run to run.

\section{CONCLUSIONS}

The results presented here show that differences in fuel composition and physical properties between ULSD and biodiesel fuels (and between different biodiesels) interact with distinct engine platforms to produce changes in the exhaust emissions of regulated air pollutants. Although the single-cylinder engine used here is a research engine, and emission levels will vary for larger diesel engines, the general trends can be used to show where further investigation could be helpful in optimizing biodiesel for use in mobile sources of emissions. Based on these results, $\mathrm{NO}_{\mathrm{x}}$ emissions are sensitive to the type of biodiesel used, particularly the HC chain length and the extent of unsaturation. In addition, adjusting engine timing for the different biodiesels reduced $\mathrm{NO}_{\mathrm{x}}$ production. Notably, in the $\mathrm{MI}$ and EI systems, the results presented here showed little to no increase in $\mathrm{NO}_{\mathrm{x}}$ emissions above those of ULSD. This finding provides further evidence that the assumed negative effects of biodiesel use on $\mathrm{NO}_{\mathrm{x}}$ emission levels may be overstated, especially when non-soy-based biodiesels are used.

With EI systems, the ability to adjust fuel injection timing to moderate the effects of biodiesel's shorter ignition delay may allow for further improvements in $\mathrm{NO}_{\mathrm{x}}$ emission levels. With respect to partial combustion products, $\mathrm{HC}$ emissions decreased with biodiesel regardless of the engine system, most likely because of the chemical makeup of the fuel, which has more straight chain HCs and molecular oxygen and little to no aromatic content. The same factors that improve $\mathrm{NO}_{\mathrm{x}}$ emissions with biodiesel in this engine tend to increase PM emissions relative to ULSD at lower engine loads. This result is particularly relevant to overall air quality impact, as the Federal Test Procedure heavy-duty diesel test cycle has an average engine operating load of $20 \%$ to $25 \%$ (24). However, the timing adjustment process somewhat mitigated the increase in PM at these lower loads while still maintaining reduced $\mathrm{NO}_{\mathrm{x}}$ emissions. Overall, trading off a decrease in $\mathrm{NO}_{\mathrm{x}}$ emissions for increased $\mathrm{PM}$ could still provide a benefit to engine manufacturers, given the emphasis on $\mathrm{NO}_{\mathrm{x}}$ levels in future emissions standards. A full assessment of this trade-off would also have to consider the relative expense and ease of use of the dif- ferent after-treatment devices used to remove $\mathrm{PM}$ and $\mathrm{NO}_{\mathrm{x}}$ from the exhaust stream, which were not considered in this study.

The results presented here have several implications for modeling the expected impacts of increased biodiesel use in various vehicles and transportation fleets. First, the different responses of mechanical and electronic fuel injection systems to biodiesel could result in notably different emissions factors from older and newer vehicles in sectors where electronic fuel injection has become more common in recent years. In addition, the different responses of the MI and EI systems across different engine loads suggest that dissimilar drive cycles could produce unique emissions profiles based on the fuel injection process. This may be one component of the observed differences in the biodiesel emissions profiles of older and newer vehicles in existing studies $(25,26)$.

Second, the potential for re-tuning of newer electronic injection engines to match biodiesel properties better should be considered as a potential strategy for limiting future emissions from biodiesel fuels, particularly as higher biodiesel content blends (B20 and beyond) become more common. This implication leads directly to the final broader impact of this study, the implications of the relationship between biodiesel composition, combustion performance, and emissions. As observed here for coconut biodiesel, as the composition of biodiesel fuels changes substantially from that of the typical current biodiesel feedstocks (soybean, canola, and rapeseed oils), the expected fuel properties and combustion performance can change substantially. As newer, second-generation biodiesel feedstocks are developed, the composition of bulk biodiesel may become more varied and combustion and emissions performance less predictable. In the end, composition-based standards for biodiesel may become a useful tool for ensuring the best performance and lowest air quality impact from these fuels.

\section{ACKNOWLEDGMENTS}

This work was partially funded by the Transportation Research Institute of the University of Kansas from a grant provided by the Research and Innovative Technology Administration of the U.S. Department of Transportation. Joshua Jachuck and Dylan Jantz participated in this work through a National Science Foundation Research Experience for Undergraduates program grant. Ray Carter of the University of Kansas Environmental Engineering Program assisted in the analysis of the biodiesel composition in 2013 and 2014.

\section{REFERENCES}

1. Energy Information Administration. Monthly Energy Review: Renewable Energy. www.eia.gov/totalenergy/data/monthly/index.cfm\#renewable. Accessed July 29, 2014

2. National Biodiesel Board. Automakers' and Engine Manufacturers' Positions of Support for Biodiesel Blends. www.biodiesel.org/using -biodiesel/oem-information/oem-statement-summary-chart. Accessed July 31,2014

3. Biodiesel Content Mandate. Minnesota Statute 239.77, 2013.

4. Requirements for Purchase of Motor-Vehicle Fuels by State Agencies. Kansas Statute 75-3744a, 2003.

5. Lapuerta, M., O. Armas, and J. Rodriguez-Fernández. Effect of Biodiesel Fuels on Diesel Engine Emissions. Progress in Energy and Combustion Science, Vol. 34, No. 2, 2008, pp. 198-223.

6. McCormick, R., A. Williams, J. Ireland, M. Brimhall, and R. Hayes. Effects of Biodiesel Blends on Vehicle Emissions. NREL/MP-540-40554. National Renewable Energy Laboratory, Golden, Colo., 2006.

7. Assessment and Standard Division. A Comprehensive Analysis of Biodiesel Impacts on Exhaust Emissions. EPA 420-P-02-001, Office of Transportation and Air Quality, U.S. Environmental Protection Agency, 2002. 
8. Hoekman, S. K., and C. Robbins. Review of the Effects of Biodiesel on $\mathrm{NO}_{\mathrm{x}}$ Emissions. Fuel Processing Technology, Vol. 96, 2012, pp. 237-249.

9. Durbin, T. D., J. W. Miller, K. J. Johnson, M. Hajbabaei, N. Y. Kado, R. Kobayashi, X. Liu, C.F.A. Vogel, F. Matsumura, P. S. Wong, and T. Cahill. CARB Assessment of the Emissions from the Use of Biodiesel as a Motor Vehicle Fuel in California Biodiesel Characterization and $N O_{x}$ Mitigation Strategy: Final Report. California Air Resources Board, Sacramento, Calif., 2011.

10. Karavalakis, G., T.D. Durbin, K.C. Johnson, and M. Hajbabaei. CARB Comprehensive B5/B10 Biodiesel Blends Heavy-Duty Engine Dynamometer Testing: Final Report. California Air Resources Board, Sacramento, Calif., 2014.

11. McCormick, R.L., M.S. Graboski, T.L. Alleman, and A. M. Herring. Impact of Biodiesel Source Material and Chemical Structure on Emissions of Criteria Pollutants from a Heavy-Duty Engine. Environmental Science and Technology, Vol. 35, No. 9, 2001, pp. 1742-1747.

12. Cecrle, E., C. Depcik, A. Duncan, J. Guo, M. Mangus, E. Peltier, S. Stagg-Williams, and Y. Zhong. Investigation of the Effects of Biodiesel Feedstock on the Performance and Emissions of a SingleCylinder Diesel Engine. Energy and Fuels, Vol. 26, No. 4, 2012, pp. 2331-2341.

13. Ye, P., and A.L. Boehman. Investigation of the Impact of Engine Injection Strategy on the Biodiesel $\mathrm{NO}_{\mathrm{x}}$ Effect with a Common-Rail Turbocharged Direct Injection Diesel Engine. Energy and Fuels, Vol. 24, 2010, pp. 4215-4225.

14. Monyem, A., J.H. Van Gerpen, and M. Canacki. The Effect of Timing and Oxidation on Emissions from Biodiesel-Fueled Engines. Transactions of the American Society of Agricultural Engineers, Vol. 44, 2001, pp. 35-42.

15. Boehman, A. L., D. Morris, and J. Szybist. The Impact of the Bulk Modulus of Diesel Fuels on Fuel Injection Timing. Energy and Fuels, Vol. 18, 2004, pp. 1877-1882.

16. Mangus, M., F. Kiani, J. Mattson, C. Depcik, E. Peltier, and S. StaggWilliams. Comparison of Neat Biodiesels and ULSD in an Optimized Single-Cylinder Diesel Engine with Electronically-Controlled Fuel Injection. Energy and Fuels, Vol. 28, No. 6, 2014, pp. 3849-3862.
17. Guo, J., E. Peltier, R. E. Carter, A. J. Krejci, S. M. Stagg-Williams, and C. Depcik. Waste Cooking Oil Biodiesel Use in Two Off-Road Diesel Engines. ISRN Renewable Energy, Vol. 2012, 2012, pp. 1-10.

18. Garcia, M., A. Gonzalo, J. L. Sanchez, J. Arauzo, and J. A. Pena. Prediction of Normalized Biodiesel Properties by Simulation of Multiple Feedstock Blends. Bioresource Technology, Vol. 101, No. 12, 2010, pp. 4431-4439.

19. Langness, C., M. Mangus, and C. Depcik. Construction, Instrumentation, and Implementation of a Low Cost, Single-Cylinder Compression Ignition Engine Test Cell. SAE Technical Paper 2014-01-0817, 2014

20. Mattson, J. M. S., M. Mangus, and C. Depcik. Efficiency and Emissions Mapping for a Single-Cylinder, Direct Injected Compression Ignition Engine. SAE Technical Paper 2014-01-1242, 2014.

21. Zhu, G. G., C. F. Daniels, and J. Winkelman. MBT Timing Detection and Its Closed-Loop Control Using In-Cylinder Pressure Signal. SAE Technical Paper 2003-01-3266, 2003.

22. Knothe, G., J. Van Garpen, and J. Krahl. The Biodiesel Handbook. AOCS Press, Champaign, Ill., 2005.

23. Benjumea, P., J. Agudelo, and A. Agudelo. Effect of the Degree of Unsaturation of Biodiesel Fuels on Engine Performance, Combustion Characteristics, and Emissions. Energy and Fuels, 2011, pp. 125-164.

24. DieselNet. Emission Test Cycles: Heavy-Duty FTP Transient Cycle. www dieselnet.com/standards/cycles/ftp_trans.php. Accessed Nov. 13, 2014

25. Farzaneh, M., J. Zietsman, D. Perkinson, and D. L. Spillane. Comparative Field Evaluation of Biodiesel Impact on Hot Stabilized Emissions from School Buses. In Transportation Research Record: Journal of the Transportation Research Board, No. 2058, Transportation Research Board of the National Academies, Washington, D.C., 2008, pp. 43-50.

26. Sandhu, G. S., and H. C. Frey. Real-World Measurement and Evaluation of Duty Cycles, Fuels, and Emission Control Technologies of HeavyDuty Trucks. In Transportation Research Record: Journal of the Transportation Research Board, No. 2270, Transportation Research Board of the National Academies, Washington, D.C., 2012, pp. 180-187.

The Standing Committee on Transportation and Air Quality peer-reviewed this paper. 